\title{
In situ probing of Gram-positive bacteria with high DNA G + C content using 235 rRNA- targeted oligonucleotides
}

\author{
Carsten Roller, Michael Wagner, Rudolf Amann, Wolfgang Ludwig and \\ Karl-Heinz Schleifer
}

Author for correspondence: Rudolf Amann. Tel: +4989 2105 2373. Fax: +498921052360.

Lehrstuhl für Mikrobiologie, Technische Universität München, Arcisstraße 16, D80290 München, Germany

\begin{abstract}
235-rRNA-targeted oligonucleotide probes were designed for the phylogenetic group ' Gram-positive bacteria with high G + C content of DNA' (GPBHGC). A sequence idiosyncrasy in two adjacent base pairs in the stem of helix 69 in domain IV of the 235 rRNA is present in all hitherto analysed strains of GPBHGC. An oligonucleotide probe targeted to this region hybridized only with strains of GPBHGC and was successfully used for in situ monitoring of these cells in activated sludge. Another unique feature of the 235 rRNA molecules of GPBHGC is a large insertion in domain III. Fluorescent oligonucleotides targeted to the highly variable regions of the rRNA within the insertions of Corynebacterium glutamicum DSM 20300', Aureobacterium testaceum DSM 20166 and Brevibacterium Sp. DSM 20165 hybridized specifically to their target strains, whereas probing with oligonucleotides complementary to the rRNA-coding strand of the 235 rDNA and to the spacer between 165 and 235 rRNA of C. glutamicum did not result in detectable fluorescence. This confirmed that the large 235 insertions are indeed present in 235 rRNAs of GPBHGC and provide potential target sites for highly specific nucleic acid probes.
\end{abstract}

Keywords: oligonucleotide probes, $23 \mathrm{~S}$ rRNA, in situ hybridization, Gram-positive bacteria, insertion

\section{INTRODUCTION}

The sequencing of rRNA molecules is not only facilitating the reconstruction of phylogenetic trees (Woese, 1987; Ludwig \& Schleifer, 1994), it is also the basis for the development of oligonucleotide probes. rRNA molecules are ideal targets for nucleic acid probes for several reasons (Stahl \& Amann, 1991), e.g. the primary structures of $16 \mathrm{~S}$ and $23 \mathrm{~S}$ rRNA are composed of sequence regions of higher and lower evolutionary conservation. Comparison of a newly retrieved rRNA sequence to the continuously growing rRNA databases allows the directed design of oligonucleotide probes complementary to more or less variable target regions. The specificity of such rRNAtargeted oligonucleotide probes can be tailored to the needs of the investigator, reaching from the subspecies (Stahl et al., 1988) to the kingdom (Giovannoni et al.,

Abbreviations: DIG, digoxigenin; GPBHGC, ' Gram-positive bacteria with high $\mathrm{G}+\mathrm{C}$ content of DNA
1988) level. Intermediate group-specific oligonucleotides complementary to sequence regions characteristic of phylogenetic entities at the genus or subclass level have been used successfully for rapid identification of bacteria (Amann et al., 1990b, 1992; Devereux et al., 1992; Manz et al., 1992). Such probes have the potential to close further the gap between standard identification schemes and our current perception of the natural classification of bacteria.

Molecular taxonomists found significant rRNA homologies between actinomycetes and a group of related bacteria, all characterized by Gram-positive staining and a high $\mathrm{G}+\mathrm{C}$ content of DNA, and consequently proposed a group named the 'actinomycetes branch' (Stackebrandt, 1991) or ' Gram-positive bacteria with high $G+C$ content of DNA' (GPBHGC; Woese, 1987). Many species of this phylogenetic group have biotechnological or medical importance. As part of an ongoing project we intended to construct a group-specific oligonucleotide probe for this important taxon of the domain Bacteria. Comparative analyses of 14 complete $23 \mathrm{~S}$ rRNA sequences of 
Table 1. List of strains with arrangement of nucleic acids on the dot-blot membrane

\begin{tabular}{|c|c|c|}
\hline Position & Organism & Source/strain* \\
\hline A. 1 & Azospirillum amazonense & DSM $2787^{T}$ \\
\hline A. 2 & Azospirillum brasilense & DSM $1690^{\mathrm{T}}$ \\
\hline A. 3 & Azospirillum balopraeferens & DSM $3675^{\mathrm{T}}$ \\
\hline A. 4 & Rhodospirillum rubrum & DSM 107 \\
\hline A. 5 & Agrobacterium tumefaciens & ATCC $23308^{\mathbf{T}}$ \\
\hline A. 6 & Bradyrbizobium japonicum & DSM $30131^{\mathrm{T}}$ \\
\hline A. 7 & Magnetospirillum gryphiswaldense & DSM $6361^{\mathrm{T}}$ \\
\hline A. 8 & Rbizobium meliloti & $\operatorname{DSM} 30135^{\mathrm{T}}$ \\
\hline A. 9 & Rhodopseudomonas palustris & $\operatorname{DSM} 123^{\mathrm{T}}$ \\
\hline A. 10 & Brevundimonas diminuta & DSM 1635 \\
\hline A. 11 & Paracoccus denitrificans & $\operatorname{DSM} 65^{\mathrm{T}}$ \\
\hline A. 12 & Rbodobacter capsulatus & DSM $1710^{\mathrm{T}}$ \\
\hline B. 1 & Thiobacillus acidopbilus & $\operatorname{DSM} 700^{\mathrm{T}}$ \\
\hline B. 2 & Zoogloea ramigera & WS 1610 \\
\hline B. 3 & Comamonas testosteroni & DSM $50244^{\mathrm{T}}$ \\
\hline B. 4 & Sphaerotilus natans & DSM 565 \\
\hline B. 5 & Aquaspirillum metamorphum & $\operatorname{DSM} 1837^{\mathrm{T}}$ \\
\hline B. 6 & Alcaligenes eutropbus & DSM $531^{\mathrm{T}}$ \\
\hline B. 7 & Alcaligenes faecalis & ATCC $8750^{\mathrm{T}}$ \\
\hline B. 8 & Chromobacterium violaceum & DSM $30191^{\mathrm{T}}$ \\
\hline B. 9 & Burkebolderia cepacia & DSM 50181 \\
\hline B. 10 & Acinetobacter calcoaceticus & LMG $1046^{\mathrm{T}}$ \\
\hline B. 11 & Alteromonas putrefaciens & DSM 50426 \\
\hline B. 12 & Leucotbrix mucor & $\operatorname{DSM} 2157^{\mathrm{T}}$ \\
\hline C. 1 & Aeromonas bydropbila & WS 1406 \\
\hline C. 2 & Vibrio anguillarum & NCIMB 2129 \\
\hline C. 3 & Escherichia coli & DSM $30083^{\mathrm{T}}$ \\
\hline C. 4 & Enterobacter aerogenes & WS 1292 \\
\hline C. 5 & Enterobacter cloacae & WS 1293 \\
\hline C. 6 & Erwinia carotovora & WS 1394 \\
\hline C. 7 & Proteus vulgaris & WS 1356 \\
\hline C. 8 & Serratia marcescens & WS 1359 \\
\hline C. 9 & Micrococcus sedentarius & DSM 20317 \\
\hline C. 10 & Pseudomonas alcaligenes & DSM $50342^{\mathrm{T}}$ \\
\hline C. 11 & Pseudomonas aeruginosa & DSM $50071^{\mathrm{T}}$ \\
\hline C. 12 & Pseudomonas pseudoalcaligenes & LMG $1225^{\mathrm{T}}$ \\
\hline D. 1 & Corynebacterium glutamicum & DSM $20300^{\mathrm{T}}$ \\
\hline D. 2 & Micrococcus luteus & $\mathrm{CCM} 169^{\mathrm{T}}$ \\
\hline D. 3 & Rhodococcus rbodocbrous & DSM 43008 \\
\hline D. 4 & Brevibacterium linens & DSM $20425^{\mathrm{T}}$ \\
\hline D. 5 & Brevibacterium sp. & DSM 20165 \\
\hline D. 6 & Pimelobacter simplex & DSM $20130^{\mathrm{T}}$ \\
\hline D. 7 & Propionibacterium freudenreichii & DSM $20271^{T}$ \\
\hline D. 8 & Flavobacterium ferrugineum & DSM $30193^{T}$ \\
\hline D. 9 & Cytophaga jobnsonae & GBF Cy jl \\
\hline D. 10 & Myxococcus fulvus & GBF Mx $\mathrm{f} 2$ \\
\hline D. 11 & Myxococcus virescens & GBF Mx v4 \\
\hline D. 12 & Pseudomonas putida & DSM $291^{\mathrm{T}}$ \\
\hline E. 1 & Bacillus cereus & $\operatorname{DSM} 31^{\mathrm{T}}$ \\
\hline E. 2 & Bacillus subtilis & ATCC 6633 \\
\hline E. 3 & Clostridium acetobutylicum & NCIMB $8052^{\mathrm{T}}$ \\
\hline E. 4 & Clostridium stercorarium & NCIMB $11754^{\mathrm{T}}$ \\
\hline E. 5 & Pectinatus frisingensis & DSM 20465 \\
\hline E. 6 & Enterococcus faecium & DSM $20477^{T}$ \\
\hline
\end{tabular}

\begin{tabular}{|lll|} 
E. 7 & Enterococcus faecalis & DSM 20478 \\
E. 8 & Lactobacillus casei & LMG 9091 \\
E. 9 & Lactococcus lactis subsp. lactis & DSM 20481 \\
E. 10 & Lactococcus lactis subsp. cremoris & DSM 20069 \\
E. 11 & Staphylococcus aureus & DSM 20231 \\
E. 12 & Streptococcus salivarius & DSM 20560 \\
F. 1 & Stapbylococcus carnosus & DSM 20501 \\
F. 2 & Hansenula anomala & DSM 70255 \\
F. 3 & Saccharomyces carlsbergensis & TUM 66 \\
F. 4 & Saccbaromyces cerevisiae & DSM 70449 \\
\hline
\end{tabular}

* ATCC, American Type Culture Collection, Rockville, MD, USA; CCM, Czechoslovak Collection of Microorganisms, Brno, Czechoslovakia; DSM, Deutsche Sammlung von Mikroorganismen und Zellkulturen, Braunschweig, Germany; GBF, Gesellschaft für Biotechnologische Forschung, Braunschweig, Germany (Professor H. Reichenbach); LMG, Laboratorium voor Microbiologie, Universiteit Gent, Ghent, Belgium; MPI, Max-PlanckInstitut für Biochemie, Martinsried/München, Germany (Dirk Schüler); NCIMB, The National Collections of Industrial and Marine Bacteria, Torry Research Station, Aberdeen, UK; TUM, Technischen Universität München, Institut für Brauereitechnologie und Mikrobiologie; WS, Institut für Mikrobiologie, Forschungszentrum für Milch und Lebensmittel, TU München, Freising/ Weihenstephan.

GPBHGC [Bifidobacterium bifidum DSM 20456, Brevibacterium linens DSM $20425^{\mathrm{T}}$, Cellulomonas flavigena DSM $20109^{\mathrm{T}}$, Corynebacterium glutamicum ASO 19, Gardnerella vaginalis DSM $4944^{\mathrm{T}}$, Nocardia asteroides DSM 43263, Propionibacterium freudenreichii DSM 20271 ${ }^{\mathrm{T}}$, Rhodococcus erytbropolis DSM 43066 ${ }^{\mathrm{T}}$ (Roller et al., 1992), Micrococcus luteus DSM $20030^{\mathrm{T}}$ (Regensburger et al., 1988), Streptomyces ambofaciens ATCC $23877^{\mathrm{T}}$ (Pernodet et al., 1989), Streptomyces griseus subsp. griseus KCTC 9080 (Kim et al., 1991), Frankia sp. (Simonet et al., 1991), Mycobacterium leprae (Liesack et al., 1991), Mycobacterium gastri ATCC 15754 (EMBL data library)] revealed both a potential target site for a group-specific oligonucleotide probe in helix 69 of the $23 \mathrm{~S}$ rRNA domain IV and a hypervariable insertion between helix 54 and 55 in the 23S rRNA domain III that could serve as a target for highly specific probes.

Whole-cell hybridization with fluorescently labelled, rRNA-targeted oligonucleotides allows the identification of individual microbial cells (DeLong et al., 1989; Amann et al., 1990a). This rapid technique for monitoring microbial populations is not limited by the problems inherent in pure culture techniques (Wagner $e t$ al., 1993) but is influenced by the abundance and accessibility of the intracellular rRNA target molecules. A correlation between growth rate, cellular rRNA content and the hybridization signal has been shown (DeLong et al., 1989; Wallner et al., 1993). The accessibility of intracellular target nucleic acids (in this case rRNA) is dependent on the permeability of the cell periphery (e.g. cell walls, cell membranes, capsules) to the probe molecules and the availability of the probe-binding site for hybridization. Not surprisingly, permeabilization of Gram-positive bac- 
Table 2. List of strains with results of whole-cell hybridization

\begin{tabular}{|c|c|c|c|c|c|}
\hline \multirow[t]{2}{*}{ Species } & \multicolumn{2}{|c|}{ Strain* } & \multicolumn{3}{|c|}{ Reaction with probe } \\
\hline & & & EUB & HGC & NHGC \\
\hline Actinomadura citrea & $43461^{\mathrm{T}}$ & DSM & + & + & - \\
\hline Actinoplanes campanulata & $43148^{\mathrm{T}}$ & DSM & + & + & ND \\
\hline Actinoplanes missouriensis & $43046^{\mathrm{T}}$ & DSM & + & + & ND \\
\hline Arthrobacter globiformis & 13344 & ATCC & + & + & - \\
\hline Arthrobacter ramosus & 1646 & $\mathrm{CCM}$ & + & + & ND \\
\hline Aureobacterium testaceum & 20166 & DSM & + & + & - \\
\hline Brevibacterium linens & $20425^{T}$ & DSM & + & + & - \\
\hline Brevibacterium sp. & 20165 & DSM & + & + & - \\
\hline Cellulomonas cellulans & 20106 & DSM & + & + & - \\
\hline Cellulomonas flavigena & 20109 & DSM & + & + & - \\
\hline Corynebacterium glutamicum & $20300^{\mathbf{T}}$ & DSM & + & + & - \\
\hline Frankia sp. & $\operatorname{Ag} 45 / \mathrm{m} 15$ & AUW & + & + & - \\
\hline Frankia sp. & AgB1.9 & AUW & + & + & ND \\
\hline Microbacterium imperiale & 20530 & DSM & + & + & - \\
\hline Micrococcus agilis & $2390^{\mathbf{T}}$ & $\mathrm{CCM}$ & + & + & ND \\
\hline Micrococcus kristinae & $27570^{\mathrm{T}}$ & ATCC & + & + & - \\
\hline Micrococcus luteus & 10240 & ATCC & + & + & ND \\
\hline Micrococcus luteus & $169^{\mathrm{T}}$ & $\mathrm{CCM}$ & + & + & - \\
\hline Micrococcus sedentarius & 20317 & DSM & + & + & ND \\
\hline Micromonospora echinospora & $43141^{\mathrm{T}}$ & DSM & + & + & ND \\
\hline Microtetraspora glauca & $23057^{\mathrm{T}}$ & ATCC & + & + & - \\
\hline Nocardia asteroides & 43263 & DSM & + & + & ND \\
\hline Nocardia calcarea & 43065 & DSM & + & + & ND \\
\hline Pimelobacter simplex & $20130^{\mathrm{T}}$ & DSM & + & + & - \\
\hline$R$ hodococcus erytbropolis & 43066 & DSM & + & + & ND \\
\hline Rhodococcus rbodocbrous & 43241 & DSM & + & + & - \\
\hline Streptomyces bumiferus & $43030^{\mathrm{T}}$ & DSM & + & + & - \\
\hline Streptomyces sp. & 118 & TUHH & + & + & - \\
\hline Streptomyces sp. & 68 & TUHH & + & + & ND \\
\hline Eubacterium lentum & 2243 & DSM & + & - & + \\
\hline Enterococcus faecium & $20477^{\mathrm{T}}$ & DSM & + & - & ND \\
\hline Streptococcus thermophilus & $20479^{\mathrm{T}}$ & DSM & + & - & + \\
\hline Lactobacillus rbamnosus & 20024 & DSM & + & - & ND \\
\hline Lactococcus lactis subsp. lactis & $20481^{\mathrm{T}}$ & DSM & + & - & ND \\
\hline Staphylococcus aureus & $20231^{\mathrm{T}}$ & DSM & + & - & ND \\
\hline Bacillus cereus & $31^{\mathrm{T}}$ & TUM & + & - & + \\
\hline Brevundimonas diminuta & 1635 & DSM & + & - & + \\
\hline Comamonas testosteroni & $50244^{\mathrm{T}}$ & DSM & + & - & + \\
\hline Eschericbia coli & $30083^{\mathrm{T}}$ & DSM & + & - & + \\
\hline Cytophaga jobnsonae & Cy j1 & GBF & + & - & + \\
\hline Myxococcus virescens & $\mathrm{Mx} v 4$ & GBF & + & - & + \\
\hline
\end{tabular}

ND, Not done.

* TUHH, Technischen Universität Hamburg-Harburg (Brigitte Böckle); AUW, Agricultural University Wageningen (Dr. Dittmar Hahn). See Table 1 for other abbreviations.

teria with their rigid cell walls has been more difficult than permeabilization of Gram-negative bacteria. Different protocols have been developed for Gram-positive bacteria: (i) fixation in $3 \%(\mathrm{w} / \mathrm{v})$ paraformaldehyde solution followed by a partial enzymic digestion of the cell wall (Hahn et al., 1992; Beimfohr et al., 1993); (ii) air-drying followed by heat-fixation (Jurtshuk et al., 1992); and (iii) fixation in an alcohol (methanol or ethanol)/formaldehyde mixture (DeLong et al., 1989; Braun-Howland et al., 1992). Another effect, the unavailability of specific rRNA target sites in permeabilized fixed cells, has only been reported recently (Amann et al., 1992) and is probably due to the higher order structure of the ribosome or rRNA. 
Table 3. Probe sequences and target sites

\begin{tabular}{|lllc|}
\hline Probe & \multicolumn{1}{c}{ Sequence } & \multicolumn{1}{c|}{ Target organism(s) } & Target site \\
\hline HGC & 5'-TATAGTTACCTCCGCCGT-3' & GPBHGC & $1901-1918^{*}$ \\
NHGC & 5'-TATAGTTACGGCCGCCGT-3' & Bacteria, not GPBHGC & $1901-1918^{*}$ \\
ATE & 5'-GAAGGGATCCGCTAAAGC-3' $^{\prime}$ & A. testaceum & $46-63 \dagger$ \\
BKE & 5'-GGTTAGCATCACTGATTCA-3' $^{\prime}$ & Brevibacterium sp. & $12-30 \dagger$ \\
CGL & 5'-TTATGGGTGGTTAGTATC-3' & C. glutamicum & $23-40 \dagger$ \\
aCGL & 5'-GATACTAACCACCCATAA-3' & C. glutamicum & $23 S$ rDNA† \\
CGLSF & 5'-ACTTTGTGTGTGGG-3' & C. glutamicum & Spacer 16S-23S, \\
& & & rDNA \\
CGLSR & 5'-CCCACACACAAAGT-3' & C. glutamicum & Spacer 16S-23S, \\
& & & rDNA \\
\hline
\end{tabular}

* rRNA position, E. coli numbering (Brosius et al., 1981).

†Insertion between helix 54a and 55a (Roller et al., 1992).

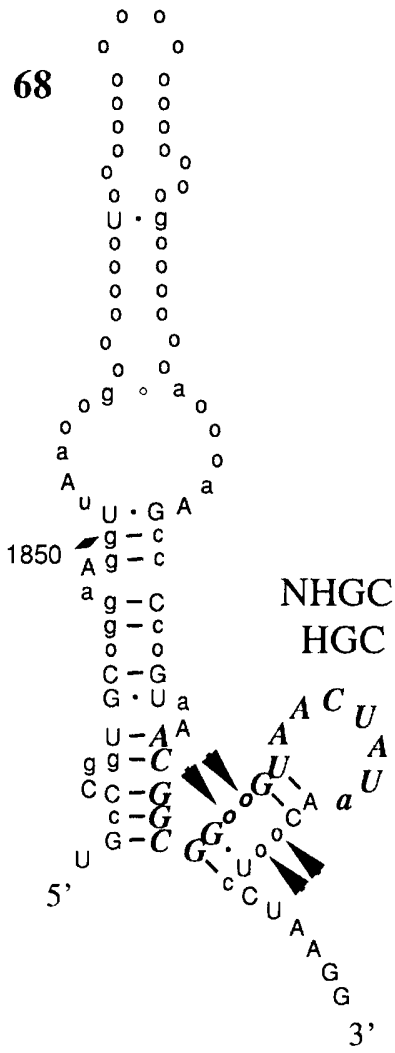

69

Fig. 1. Secondary structure model of part of domain IV of bacterial 235 rRNA. The consensus sequence shown is based on a data set of about 100 complete 23S rRNA sequences from representatives of all bacterial phyla. Invariant residues are indicated by upper-case letters, those which are invariant in at least $90 \%$ of the sequences are indicated as lower-case letters and less conserved positions are represented by circles. The target site of probes HGC and NHGC is visualized by bold italics. Arrowheads highlight the signature positions. Base numbering is according to Brosius et al. (1981); helix numbering is according to Höpfl et al. (1989).

In this study, cell fixation and hybridization parameters were optimized for whole cell identification of GPBHGC, and probes directed against characteristic sequence regions-so-called signatures - on the $23 \mathrm{~S}$ rRNA were evaluated.

\section{METHODS}

Organisms and culture conditions. Sources and strain numbers of the organisms investigated in this study are listed in Tables 1 and 2. Cells were cultured as described in the catalogues of strains of the DSM (Deutsche Sammlung von Mikroorganismen und Zellkulturen, Braunschweig, Germany), ATCC (American Type Culture Collection, Rockville, MD, USA) or CCM (Czechoslovak Collection of Microorganisms, Brno, Czechoslovakia) or were kindly provided by various investigators (see Tables 1 and 2)

Cell fixation. Cells growing in exponential phase $\left(\mathrm{OD}_{600}\right.$ between 0.5 and 0.8 ) were harvested by centrifugation ( $2 \mathrm{~min}$, $5000 \mathrm{~g}$ ) and washed in phosphate-buffered saline (PBS; $130 \mathrm{mM}$ $\mathrm{NaCl}, 10 \mathrm{mM}$ sodium phosphate buffer, $\mathrm{pH} 7 \cdot 4$ ). Gram-positive bacteria were resuspended in PBS and fixed by addition of ethanol $(50 \%, v / v)$. Activated sludge was fixed at the time of sampling by addition of ethanol to a final concentration of $50 \%$. Gram-negative bacteria were fixed for $3 \mathrm{~h}$ in $3 \%$ paraformaldehyde/PBS, washed in PBS and finally resuspended (Amann $e t$ al., 1990b). All cells were stored in PBS $/ 96 \%$ ethanol $(1: 1, \mathrm{v} / \mathrm{v})$ at $-20^{\circ} \mathrm{C}$.

Oligonucleotide probes. All probe sequences are given in Table 3. Oligonucleotide probes were synthesized with a C6TFA aminolinker [6-(trifluoracetylamino)-hexyl-(2-cyanoethyl)-( $N, N$-diisopropyl)phosphoramidite] at the $5^{\prime}$-end (MWG Biotech). Labelling with tetramethylrhodamine-5-isothiocyanate (TRITC; Molecular Probes) and 5(6)-carboxyfluorescein- $N$-hydroxysuccinimide ester (FLUOS; Boehringer Mannheim) and purification of the oligonucleotide dye conjugates was performed as described by Amann et al. (1990a). Probes were also labelled with digoxigenin (DIG) following the protocols of Zarda et al. (1991).

Whole-cell hybridization. Fixed cells were spotted on precleaned, gelatin-coated $\left[0.1 \%\right.$ gelatin, $\left.0.01 \% \mathrm{KCr}\left(\mathrm{SO}_{4}\right)_{2}\right]$ microscopic slides (Paul Marienfeld KG, Bad Mergentheim, Germany), and immobilized by drying at $46^{\circ} \mathrm{C}$ for $15 \mathrm{~min}$. A series of immersions in $50 \%, 80 \%$ and $96 \%(\mathrm{v} / \mathrm{v})$ ethanol 


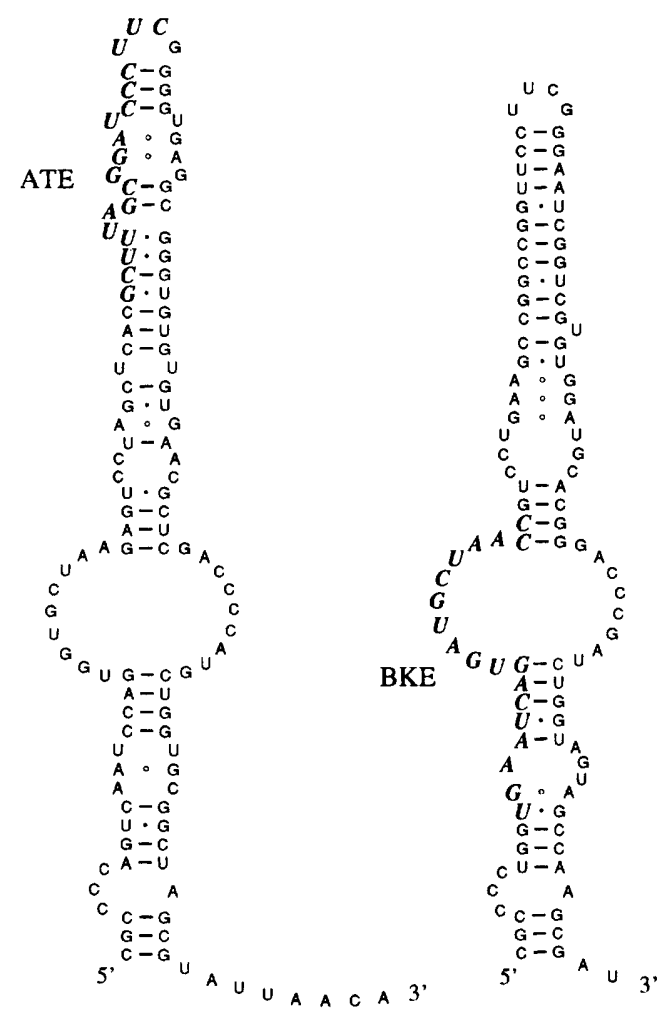

A. testaceum

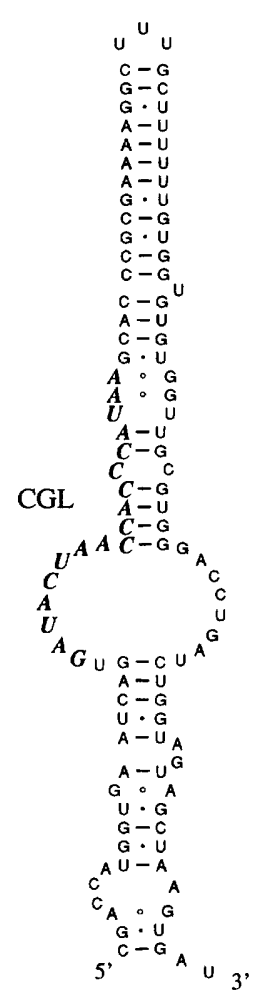

C. glutamicum
Fig. 2. Potential secondary structure models of the large stable insertions in domain III (Roller et al., 1992) of the 235 rRNA molecules of $A$. testaceum, Brevibacterium sp. and C. glutamicum. Target sites of probes ATE (targeting $A$. testaceum), BKE (Brevibacterium sp.) and CGL (C. glutamicum) are highlighted by bold italics.
( 3 min each) completed the fixation. Samples of $8 \mu$ hybridization solution $(0.9 \mathrm{M} \mathrm{NaCl}, 20 \mathrm{mM}$ Tris/ $\mathrm{HCl}, \mathrm{pH} 7.2,0.01 \%$ SDS, $50 \mathrm{ng}$ probe, $\mathrm{X} \%$ formamide) were applied to each well of the microscopic slide and incubated for $3-4 \mathrm{~h}$ in an isotonically equilibrated humidity chamber. The probe was removed from the slide by rinsing with $2 \mathrm{ml}$ prewarmed washing solution (20 $\mathrm{mM}$ Tris/ $\mathrm{HCl}, 0.01 \%$ SDS, $5 \mathrm{mM}$ EDTA, Y M NaCl; the salt concentration, $Y$, was adjusted to the formamide concentration, $\mathrm{X}$, in the hybridization buffer as described by Manz et al., 1992). Slides were rapidly transferred into washing solution and incubated at $48^{\circ} \mathrm{C}$ for $20 \mathrm{~min}$. Slides were rinsed briefly with distilled water, air-dried and mounted in Citifluor solution.

Slides were examined using a Zeiss Axioplan microscope fitted for epifluorescence microscopy with a $50 \mathrm{~W}$ mercury highpressure bulb and Zeiss filter sets nos 09 and 15. Black-andwhite photomicrographs were done on Kodak Tmax 400. Exposure times were 0.06 s for phase contrast and 15-30 s for epifluorescence micrographs.

Quantification of probe-conferred fluorescence. To determine the optimal hybridization stringency the signals conferred by the fluorescein-labelled oligonucleotide probe HGC, specific for GPBHGC, was determined at different formamide concentrations in the hybridization buffer by image analysis according to Trebesius et al. (1994). Formamide can be used to influence the sensitivity and specificity of hybridization (Stahl \& Amann, 1991)

Dot-blot analysis. Oligonucleotide probe specificity was examined by hybridization of DIG-labelled probes to reference nucleic acids extracted from 64 pure cultures of bacteria and eukarya representing a diverse collection of taxa. Reference nucleic acids were isolated using a modification of the method of Oelmüller et al. (1990). Cells (usually $2 \mathrm{ml}$ cell suspension) were harvested by centrifugation $\left(10 \mathrm{~min} ; 18000 \mathrm{~g} ; 4^{\circ} \mathrm{C}\right)$ in a Hettich centrifuge 2021, washed with acetate/EDTA (AE) buffer (20 $\mathrm{mM}$ sodium acetate, $1 \mathrm{mM}$ disodium EDTA, $\mathrm{pH} 5 \cdot 5 ; 0{ }^{\circ} \mathrm{C}$ ) and resuspended in a mixture of $400 \mu \mathrm{l} \mathrm{AE}$ buffer and $50 \mu \mathrm{l} 25 \%$ $(\mathrm{w} / \mathrm{v})$ SDS. Gram-positive cells and yeast cells were mechanically disrupted using glass beads $(0.17 \mathrm{~mm}$ diameter $)$ in combination with sonication $(2 \mathrm{~min})$. Nucleic acids of all cells were purified by phenol extraction followed by ethanol precipitation (Manz et al., 1992). The concentration of nucleic acids was determined spectrophotometrically by measuring the $A_{\mathbf{2 6 0}}$. Isolated reference nucleic acids were immobilized on nylon membranes (Diagen) using a dot-blot apparatus (Schleicher and Schuell). Probing with DIG-labelled oligonucleotides was done as described previously (Manz et al., 1992).

\section{RESULTS AND DISCUSSION}

\section{Design of oligonucleotide probes}

The longest coherent structure of highly conserved residues within the primary structure of bacterial $23 \mathrm{~S}$ rRNAs comprises 83 bases of domain IV (Höpfl et al., 1989; Larsen, 1992; Ludwig \& Schleifer, 1994; positions 1889-1971, Escherichia coli numbering, Brosius et al., 1981). A potential secondary structure model of part of domain IV (helices 68 and 69; Fig. 1) is shown for a consensus sequence derived from a data set of complete $23 \mathrm{~S}$ rRNA sequences from representatives of all bacterial phyla (Woese, 1987). Within the stem of helix 69 most bacterial sequences contain CC in positions 1908-1909 (E. 
(a)
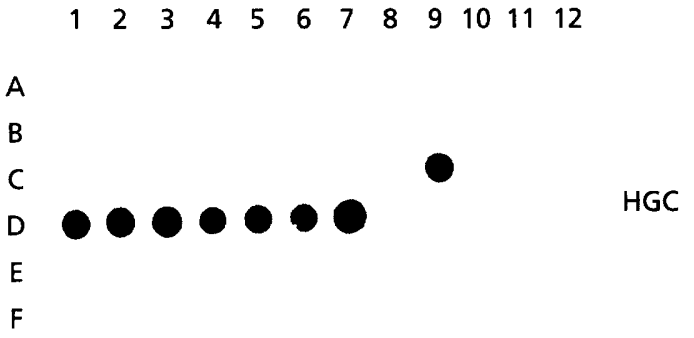

(b)

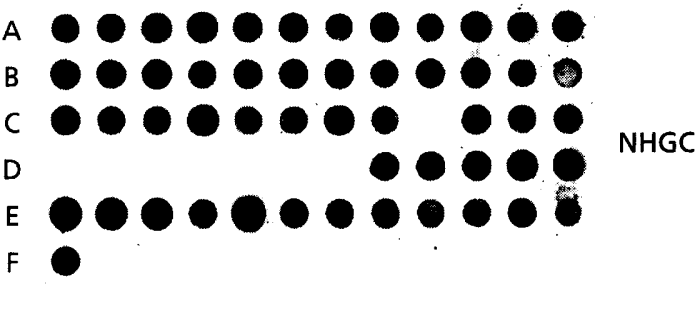

(c)

D

E

$F$

(d)

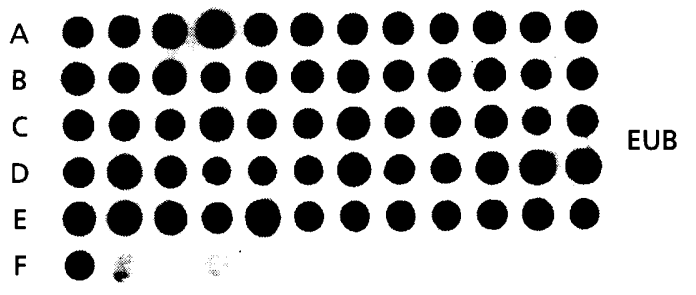

Fig. 3. Dot-blot analysis of probe specificities. Nucleic acids were isolated from 64 reference organisms (see Table 2 for list of strains and arrangement). Membranes were hybridized from top to bottom with probes HGC, NHGC, CGL and EUB.

coli numbering), presumably paired with GG (1912-1913). However, all $23 \mathrm{~S}$ rRNA sequences so far determined for GPBHGC have AG/CU (1908-1909/1912-1913) in place of CC/GG. In the construction of a probe best exploiting this sequence idiosyncrasy, probe HGC was designed as an 18mer complementary to positions 1901-1918. Another 18mer also binding at positions 1901-1918 and complementary to the homologous region in the $23 \mathrm{~S}$ rRNA of all bacteria other than GPBHGC was designated NHGC. It has recently been demonstrated that mismatch discrimination can be enhanced by competitive hybridization with two oligonucleotides targeted to homologous regions (Manz et al., 1992). Therefore, the combined use of probes HGC and NHGC can be of advantage for the specificity of the assay.

The presence of large stable insertions (about 100 bases) within domain III of the 23S rRNA has been shown to be a signature for the GPBHGC (Roller et al., 1992). The primary structures of the insertions are evolutionarily only moderately conserved and thus provide potential target sites for species-specific probes. Based on partial $23 \mathrm{~S}$ rRNA sequences of Aureobacterium testaceum, Brevibacterium sp. (formerly B. ketoglutamicum) and C. glutamicum, probes ATE, BKE and CGL (Roller et al., 1992) were designed complementary to parts of the large insertion between helices 54 and 55 . These probes target different regions (see Table 1 and Fig. 2) within this insertion and were used to test for the presence and accessibility of their target sequences on mature $23 \mathrm{~S}$ rRNA molecules. All of the following oligonucleotides served as controls during whole cell hybridization: aCGL is complementary to CGL and is a control for non-specific binding and for binding to the rRNA genes (rDNA) of C. glutamicum; CGLSR is targeted at the 16S-23S spacer on the precursor-like strand on the rRNA operon and the precursor of $C$. glutamicum, whereas CGLSF is targeted to the precursor-coding strand of the rRNA operon. Probe EUB is complementary to a region of the $16 \mathrm{~S} r \mathrm{RNA}$ conserved for Bacteria (Amann et al., 1990b) and was used as positive control for the permeability of the fixed Grampositive cells to rRNA-targeted oligonucleotides. All probe sequences are given in Table 3.

\section{Fixation of GPBHGC for whole-cell hybridization}

Initial experiments were performed with exponentially growing cells of C. glutamicum, A. testaceum, and Brevibacterium sp. that had been fixed in $3 \%$ paraformaldehyde for several hours and stored in ethanol/PBS $(1: 1, \mathrm{v} / \mathrm{v})$ (Amann et al., 1990b). Whole-cell hybridization with fluorescent derivatives of the bacterial probe EUB or the specific probes did not result in reliable visualization of target cells (data not shown). Since cells were taken from cultures growing at short generation times (approx. $1 \mathrm{~h}$ ) cellular ribosome contents were probably high enough for detection, and the failure in detection was most likely due to the limited permeabilities of the fixed cells to probes. Treatment of paraformaldehyde-fixed cells with lysozyme has been shown to increase the permeability of Gram-positive streptococci (Beimfohr et al., 1993) and Streptomyces scabies hyphae (Hahn et al., 1992), but it did not significantly influence hybridization signals of $C$. glutamicum, A. testaceum and Brevibacterium sp. However, fixation in $50 \%$ ethanol yielded cell preparations that showed homogeneous, strong hybridization with fluorescently labelled probes (Fig. 4). This supports recently published results that paraformaldehyde fixation is not required (Jurtshuk et al., 1992) and is even detrimental (Braun-Howland et al., 1992) to whole cell hybridization of Gram-positive bacteria.

\section{Determination of optimal hybridization conditions}

By gradually increasing the formamide concentration at a fixed incubation temperature the hybridization stringency was optimized for each probe to achieve an optimal 
(a)

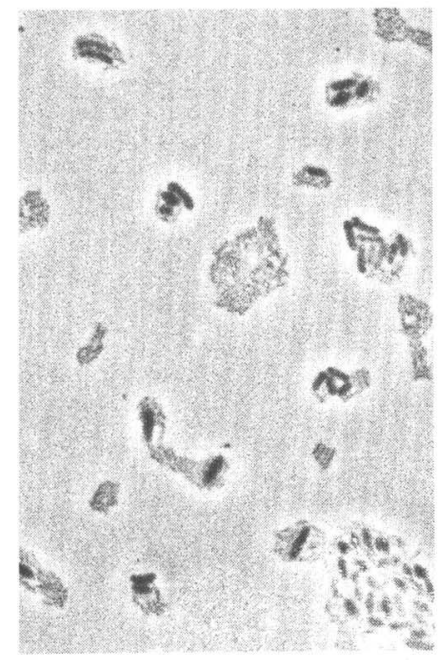

(b)

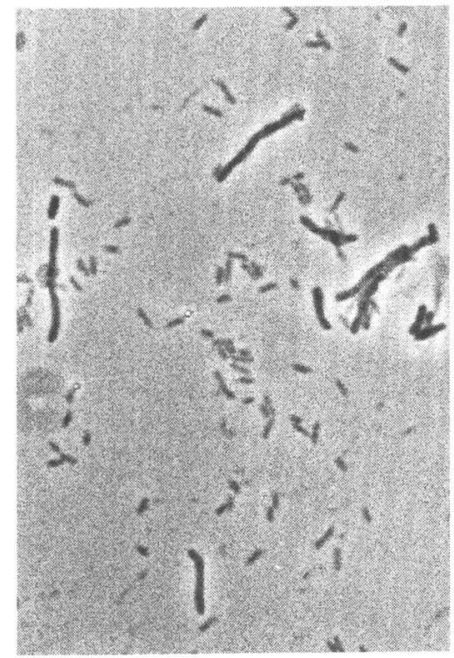

(c)

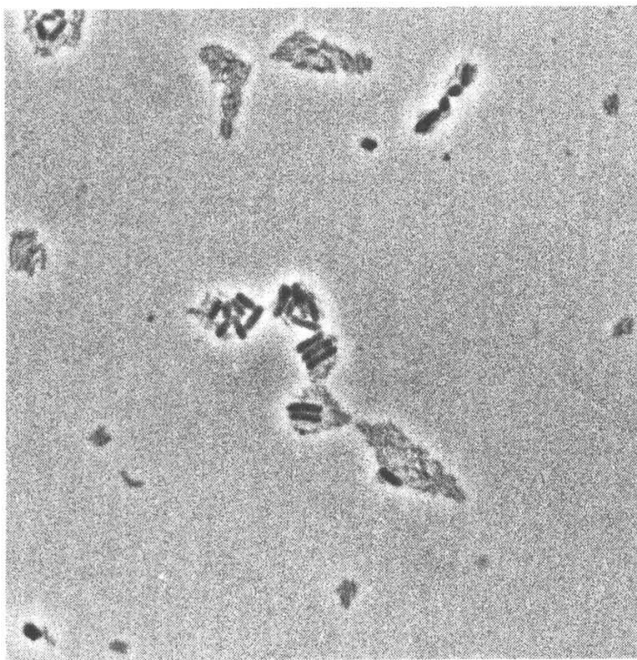

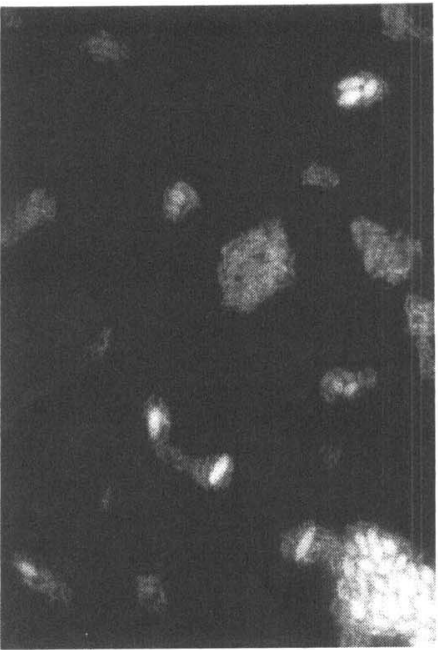
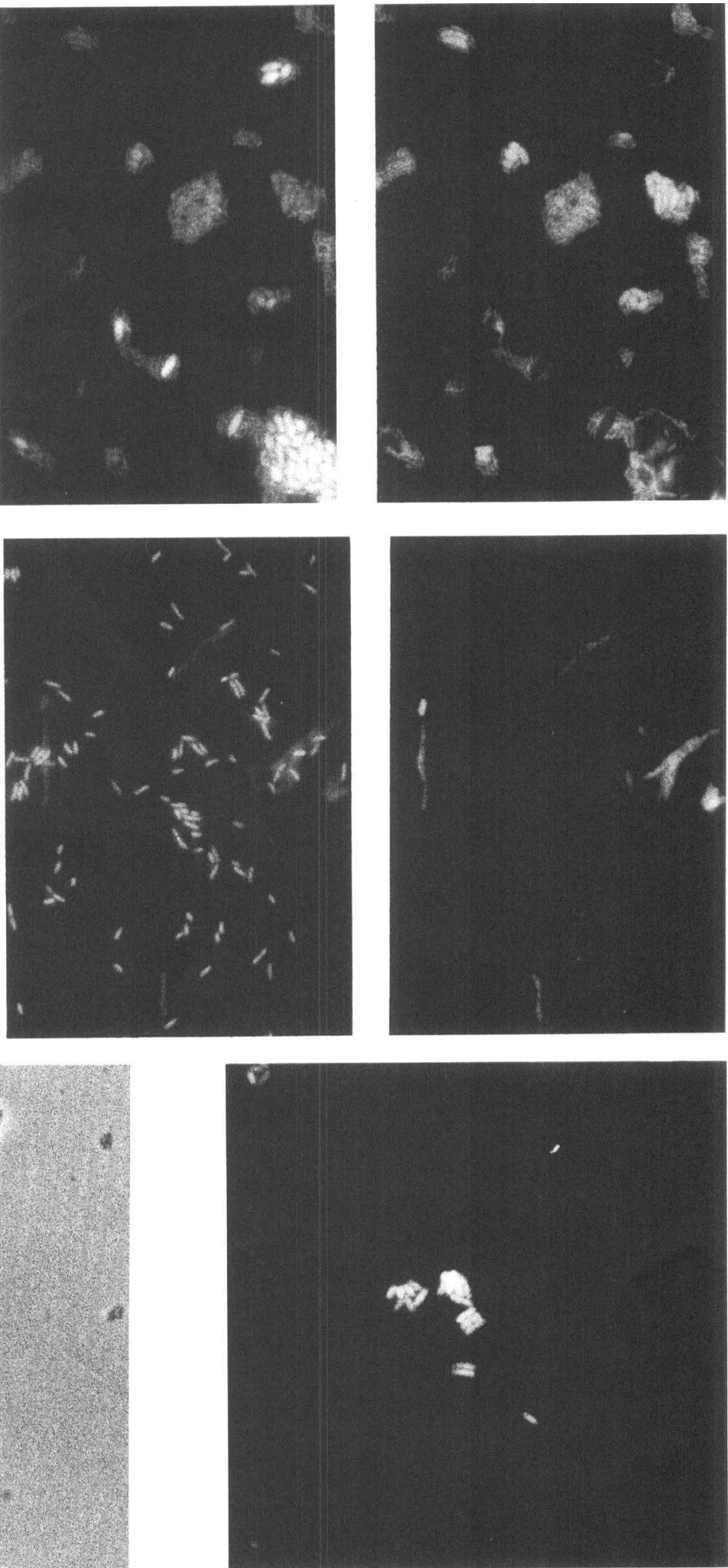

Fig. 4. Whole-cell hybridization. Panel (a) Cells of Streptococcus thermophilus (coccoid rods), C. glutamicum (irregular rods) and Microbacterium imperiale (thin rods) were hybridized with fluorescein-labelled probe EUB and tetramethylrhodamine-labelled probe HGC. Identical fields were viewed with phase contrast (left) and epifluorescence microscopy using a fluorescein- (centre) and rhodamine-specific filter set. All three cell types have bound bacterial probe EUB; only cells of $M$. imperiale and C. glutamicum have bound probe HGC. Panel (b) Cells of C. glutamicum, Brevibacterium sp. (long, irregular rods) and Pseudomonas diminuta (thin rods) were hybridized with fluorescein-labelled probe NHGC and tetramethylrhodamine-labelled probe HGC. After hybridization $P$. diminuta cells were visualized using 
balance between specificity and sensitivity. The average fluorescence signals were quantified by digital image microscopy (data not shown). At formamide concentrations of $25 \%(\mathrm{v} / \mathrm{v})$ for probes HGC and NHGC and $0 \%$ for CGL, ATE and BKE the probes distinguished clearly between target and non-target cells.

\section{Evaluation of probe specificities}

Under optimal hybridization conditions, the specificities of probes HGC (complementary of the GPBHGC), NHGC (complementary to all other bacteria), CGL (complementary to C. glutamicum), ATE (complementary to A. testaceum; data not shown) and BKE (complementary to Brevibacterium sp.; data not shown) were experimentally evaluated in two ways.

DIG-labelled probes were used for dot-blot hybridization against nucleic acids extracted from 64 reference strains (Table 1). These reference strains were selected to cover the important phylogenetic groups within the domain Bacteria and included eight GPBHGC. Probes HGC and NHGC showed the expected specificities (Fig. 3, panels a and $b$ ). As expected probe CGL only hybridized to nucleic acids extracted from C. glutamicum (Fig. 3, panel c). Hybridization with the bacterial probe EUB (Fig. 3, panel d) served as positive control.

Whole-cell hybridizations with fluorescent derivatives of probes HGC, NHGC and EUB were performed on defined mixtures of target and non-target cells. The results are in accordance with the known phylogenetic affiliations of the hybridized cells (Table 2). Representative photomicrographs are shown in Fig. 4, panels (a) and (b).

\section{Whole-cell hybridization to the large 235 rRNA insertion of GPBHGC}

Using the optimized fixation protocol, cells of C. glutamicum, $A$. testaceum and Brevibacterium sp. could be specifically visualized with the fluorescently mono-labelled probes CGL (Fig. 4, panel c), ATE and BKE (not shown), respectively. These results indicated accessibility of the probes to the target regions and their occurrence in relatively high numbers per cell. Control hybridizations with fluorescently labelled probe CGLSR targeted to the $16 \mathrm{~S}-23 \mathrm{~S}$ spacer (present in the precursor and excised in mature rRNA) and probes aCGL and CGLSF, complementary to CGL and CGLSR, did not result in detectable probe-conferred fluorescence. These data corroborate earlier findings obtained by Southern and Northern hybridization and sequencing that the large $23 \mathrm{~S}$ rDNA insertion of GPBHGC is not removed during the maturation of precursor rRNA (Roller et al., 1992), in
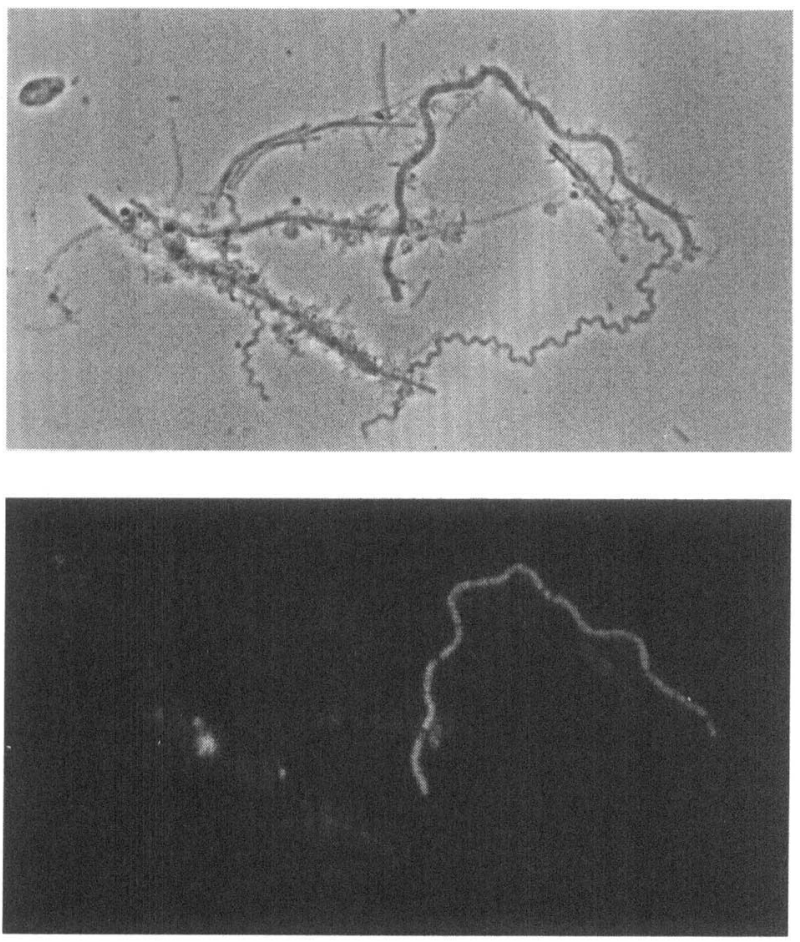

Fig. 5. In situ detection of filamentous bacteria in activated sludge with fluorescein-labelled probe HGC. Phase-contrast (upper panel) and epifluorescence micrographs (lower panel) are shown for an identical microscopic field.

contrast to the $23 \mathrm{~S}$ rDNA insertions in other bacteria (e.g. Burgin et al., 1990; Skurnik \& Toivanen, 1991). It also demonstrates that fluorescent oligonucleotides can be tools to rapidly prove the presence of insertions in mature rRNA molecules and to distinguish these stable insertions from those which are removed during rRNA processing.

\section{In situ hybridization with probe HGC}

Fluorescently labelled, group-specific oligonucleotide probes have been successfully used for in situ monitoring of population changes in complex microbial communities such as sulfidogenic biofilms (Amann et al., 1992) or activated sludge (Wagner et al., 1993). Rapid and reliable monitoring of GPBHGC in activated sludge would be beneficial since these bacteria have been connected with malfunctions such as foaming or bulking (Blackall et al., 1989, 1991 ; Lemmer \& Kroppenstedt, 1984). Hybridization of activated-sludge samples with probe HGC resulted in the visualization of specific morphotypes, e.g. filamentous bacteria (Fig. 5). There was a marked influence of sample fixation on the number of cells

the fluorescein-specific filter set (centre) and cells of C. glutamicum and Brevibacterium sp. were visualized using the rhodamine-specific filter set. Panel (C) Tetramethylrhodamine-labelled probe CGL allows specific detection of $C$ glutamicum in a mixture of $S$. thermophilus, $C$. glutamicum and $M$. imperiale. Phase-contrast (left) and epifluorescence (right) micrographs are shown for an identical field. 
detected by probe HGC. W'hen the sample had been fixed in paraformaldehyde only $10 \cdot 7 \pm 3.5 \%$ of the cells detected with the DNA-intercalating dye 4',6-diamidino-2phen lindole (DAPI) were visualized by probe HGC, but, when the sample had been fixed in ethanol, $22 \cdot 9 \pm 6.6 \%$ hybricized with probe HGC. This clearly showed the importance of adequate sample preparation for quantitative monitoring of groups by in situ probing (Manz et al., 1994).

Gram-staining was positive for most of the morphologically distinct cell types detected by probe HGC, but proved difficult to interpret in activated-sludge samples. Thus, for the in situ monitoring of GPBHGC, fluorescent oligonucleotide probing could become a valuable complement to standard staining techniques and immunofluorescence. Simultaneous hybridization of probe HGC with differently labelled probes for the alpha-, beta-, and ganma-subclasses of Proteobacteria (Manz et al., 1992) and another group-specific probe detecting members of the genera Cytophaga, Flavobacterium and Flexibacterium, currently under development, did in no case result in dual staining of cells, indicating that these probes indeed detect separate groups. This is important since the diversity of complex microbial communities (such as activated sludge) is today only partially known. Therefore even an extensive evaluation of databases and reference strains cannot guarantee the intended specificity of probes.

\section{ACKNOWLEDGEMENTS}

Thin work was supported by a grant from the European Communities EEC Contact BIOT-CT91-0294. The excellent technical assistance of Mrs Sibylle Schadhauser is acknowledged.

\section{REFERENCES}

Amann, R. I., Binder, B. J., Olson, R. J., Chisholm, S. W., Devereux, R. \& Stahl, D. A. (1990a). Combination of $16 \mathrm{~S}$ rRNA-targeted oligronucleotide probes with flow cytometry for analyzing mixed microbial populations. App/ Envrion Microbiol 56, 1919-1925.

Amann, R. I., Krumholz, L. \& Stahl, D. A. (1990b). Fluorescentoligronucleotide probing of whole cells for determinative, phylogenctic, and environmental studies in microbiology. I Bacteriol 172, 762770 .

Amann, R., Stromley, J., Devereux, R., Key, R. \& Stahl, D. A. (1992). Molecular and microscopic identification of sulfate-reducing bacteria in multispecies biofilms. Appl Environ Microbiol 58, $61+623$.

Beimfohr, C., Krause, A., Amann, R., Ludwig, W. \& Schleifer, K. H. (1993). In situ identification of lactococci, enterococci and streptococci. Syst Appl Microbiol 16, 450-456.

Blackall, L. L., Parlett, J. H., Hayward, A. C., Minnikin, D. E., Greenfield, P. F. \& Harbers, A. E. (1989). Nocardia pinensis sp. nov., an actinomycete found in activated sludge foams in Australia. J Gen Mlirobiol 135, 15471558.

Blackall, L. L., Harbers, A. E., Greenfield, P. F. \& Hayward, A. C. (1991). Foaming in activated sludge plants: a survey in Queensland, lustralia and an evaluation of some control strategies. W'ater Res 25. 313317.

Braun-Howland, E. B., Danielsen, S. A. \& Nierzwicki-Bauer, S. A.
(1992). Development of a rapid method for detecting bacterial cells in situ using 16S rRNA-targeted probes. Biotechniques 13, $928-933$. Brosius, J., Dull, T. J., Sleeter, D. D. \& Noller, H. F. (1981). Gene organization and primary structure of a ribosomal RN A operon from Escherichia coli. J Mol Biol 148, 107127.

Burgin, A., Parodos, K., Lane, D. J. \& Pace, N. (1990). The excision of intervening sequences from salmonella $23 \mathrm{~S}$ ribosomal RNA. Cell 60, 405-414.

DeLong, E. F., Wickham, G. S. \& Pace, N. R. (1989). Phylogenetic stains: ribosomal RNA-based probes for the identification of single microbial cells. Science 243, 1360-1363.

Devereux, R., Kane, M. D., Winfrey, J. \& Stahl, D. A. (1992). Genus- and group-specific hybridization probes for determinative and environmental studies of sulfate-reducing bacteria. Syst . Appl Microbiol 15, 601-609.

Giovannoni, S. J., DeLong, E. F., Olsen, G. J. \& Pace, N. R. (1988). Phylogenetic group-specific oligodeoxynucleotide probes for identification of single microbial cells. J Bacteriol 170, 720-726.

Hahn, D., Amann, R., Ludwig, W., Akkermans, A. D. L. \& Schleifer, K. H. (1992). Detection of micro-organisms in soil after in situ hybridization with rRNA-targeted, fluorescently labelled oligonucleotides. J Gen Microbiol 138, 879887.

Höpfl, P., Ludwig, W., Schleifer, K. H. \& Larsen, N. (1989). The 23S ribosomal RNA higher-order structure of Pseudomonas cepacia and other prokaryotes. Eur J Biochem 185, 355 364.

Jurtshuk, R. J., Blick, M., Bresser, J., Fox, G. E. \& Jurtshuk, P. (1992). Rapid in situ hybridization technique using $16 \mathrm{~S}$ rRNA segments for detecting and differentiating the closely rclated grampositive organisms Bacillus polymyxa and Bacillus macerans. Appl Environ Microbiol 58, 2571-2578.

Kim, E., Kim, H., Kang, K., Kho, Y. \& Park, Y. H. (1991). Complete nucleotide sequence of a $16 \mathrm{~S}$ ribosomal RNA gene from Streptomyces griseus subsp. griseus. Nucleic Acids Res 19, 1149.

Larsen, N. (1992). Higher order interaction in 23S rRNA. Proc Natl Acad Sci LS.A 89, 5044-5048.

Lemmer, H. \& Kroppenstedt, R. M. (1984). Chemotaxonomy and physiology of some actinomycetes isolated from scumming activated sludge. Syst. Appl Microbiol 5, $124-135$.

Liesack, W. C., Sela, S., Bercovier, H., Pitulle, C. \& Stackebrandt, E. (1991). Complete nucleotide sequence of Mycobacterium leprae $23 \mathrm{~S}-5 \mathrm{~S}$ genes plus flanking regions and their potential in designing diagnostic oligonucleotide probes. FEBS Lett 281, 114-118.

Ludwig, W. \& Schleifer, K. H. (1994). Bacterial phylogeny based on $16 \mathrm{~S}$ and $23 \mathrm{~S}$ rRNA sequence analyses. FEMS Microbiol Rev" (in press).

Manz, W., Amann, R., Ludwig, W., Wagner, M. \& Schleifer, K. H. (1992). Phylogenetic oligodeoxynucleotide probes for the major subclasses of proteobacteria: problems and solutions. Syst Appl Microbiol 15, 593-600.

Manz, W., Wagner, M., Amann, R. \& Schleifer, K. H. (1994). In situ characterization of the microbial consortia active in two wastewater treatment plants. Water Res 28, 1715-1723.

Oelmüller, U., Krüger, N., Steinbüchel, A. \& Friedrich, C. G. (1990). Isolation of prokaryotic RNA and detection of specific $m R N A$ with biotinylated probes. J Microbiol Methods 11, 73-84.

Pernodet, J. L., Boccard, F., Alegre, M.-T., Gagnat, J. \& Guerineau, M. (1989). Organisation and nucleotide sequence of a ribosomal RNA gene cluster from Streptomyces ambofaciens. Gene 76, 33-46.

Regensburger, A., Ludwig, W., Frank, R., Blöcker, H. \& Schleifer, K. H. (1988). Complete nucleotide sequence of a $23 \mathrm{~S}$ ribosomal RNA gene from Micrococcus luteus. Nucleic.Acids Res 16, 2344. 
Roller, C. (1993). Vergleichende sequenzanalysen der 23S-ribosomalen $\mathrm{RNS}$ von actinomyceten und verwandten organismen. $\mathrm{PhD}$ thesis, Technische Universität München, Germany.

Roller, C., Ludwig, W. \& Schleifer, K. H. (1992). Gram-positive bacteria with a high $\mathrm{G}+\mathrm{C}$ content are characterized by a common insertion within their 23S rRNA genes. J Gen Microbiol 138, 1167-1175.

Simonet, P., Grosjean, M. C., Misra, A. K., Nazaret, S., Cournoyer, B. \& Normand, P. (1991). Frankia genus-specific characterization by polymerase chain reaction. Appl Environ Microbiol 57, 3278-3286.

Skurnik, M. \& Toivanen, P. (1991). Intervening sequences (IVSs) in the $23 \mathrm{~S}$ ribosomal RNA genes of pathogenic Yersinia enterocolytica strains. The IVSs in Y. enterocolytica and Salmonella typhimurium have a common origin. Mol Microbiol 57, 1468-1477.

Stackebrandt, E. (1991). Unifying phylogeny and phenotypic diversity. In The Prokaryotes. 2nd edn, pp. 19-47. Edited by A. Balows, H. G. Trüper, M. Dworkin, W. Harder \& K. H. Schleifer. New York: Springer-Verlag.

Stahl, D. A. \& Amann, R. I. (1991). Development and application of nucleic acid probes in bacterial systematics. In Sequencing and Hybridization Techniques in Bacterial Systematics, pp. 205-248. Edited by E. Stackebrandt \& M. Goodfellow. Chichester: John Wiley and Sons.
Stahl, D. A., Flesher, B., Mansfield, H. R. \& Montgomery, L. (1988). Use of phylogenetically based hybridization probes for studies of ruminal microbial ecology. Appl Environ Microbiol 54, 1079-1084.

Trebesius, K., Amann, R., Ludwigs, W., Mühlegger, K. \& Schleifer, K. H. (1994). Identification of whole fixed bacterial cells with nonradioactive $23 \mathrm{~S}$ rRNA-targeted polynucleotide probes. Appl Environ Microbiol 60 (in press).

Wagner, M., Amann, R., Lemmer, H. \& Schleifer, K. H. (1993). Probing activated sludge with oligonucleotides specific for proteobacteria : inadequacy of culture-dependent methods for describing microbial community structure. Appl Environ Microbiol 59, 1520 1525.

Wallner, G., Amann, R. \& Beisker, w. (1993). Optimizing fluorescent in situ hybridization with rRNA-targeted oligonucleotide probes for flow cytometric identification of microorganisms. Cytometry 14, 136-143.

Woese, C. R. (1987). Bacterial evolution. Microbial Rev 51, 221-271.

Zarda, B., Amann, R., Wallner, G. \& Schleifer, K. H. (1991). Identification of single bacterial cells using digoxigenin-labelled, rRNA-targeted oligonucleotides. J Gen Microbiol 137, 2823-2830.

Received 28 February 1994; revised 14 June 1994; accepted 1 July 1994. 